\title{
Rewilding Lite: Using Traditional Domestic Livestock to Achieve Rewilding Outcomes
}

\author{
Iain J. Gordon ${ }^{1,2,3,4,5, * \mathbb{C}}$, F. Javier Pérez-Barbería ${ }^{6}$ and Adrian D. Manning ${ }^{2}$ (D) \\ 1 Fenner School of Environment and Society, The Australian National University, \\ Canberra, ACT 0200, Australia \\ 2 James Hutton Institute, Aberdeen AB15 8QH, UK; adrian.manning@anu.edu.au \\ 3 Central Queensland University, Townsville, QLD 4810, Australia \\ 4 Land \& Water, CSIRO, Townsville, QLD 4810, Australia \\ 5 Protected Places Mission, NESP2, Reef and Rainforest Research Center, Cairns, Qld 4870, Australia \\ 6 Department of Agroforestry Science and Technology and Genetics, IDR, University of Castilla-La Mancha \\ IREC, 02071 Albacete, Spain; j.perezbarberia@gmail.com \\ * Correspondence: iain.gordon@anu.edu.au; Tel.: +61-447411258
}

Citation: Gordon, I.J.; Pérez-Barbería, F.J; Manning, A.D. Rewilding Lite: Using Traditional Domestic Livestock to Achieve Rewilding Outcomes. Sustainability 2021, 13, 3347. https://doi.org/10.3390/su13063347

Academic Editor: C. Ronald Carroll

Received: 11 February 2021

Accepted: 11 March 2021

Published: 18 March 2021

Publisher's Note: MDPI stays neutral with regard to jurisdictional claims in published maps and institutional affiliations.

Copyright: () 2021 by the authors. Licensee MDPI, Basel, Switzerland. This article is an open access article distributed under the terms and conditions of the Creative Commons Attribution (CC BY) license (https:// creativecommons.org/licenses/by/ $4.0 /)$.

\begin{abstract}
The vision of rewilding is to return ecosystems to a "natural" or "self-willed" state with trophic complexity, dispersal (and connectivity) and stochastic disturbance in place. The concept is gaining traction, particularly in Europe where significant land abandonment has taken place in recent years. However, in reality, the purest form of rewilding (Rewilding Max) is constrained by a number of context-specific factors whereby it may not be possible to restore the native species that form part of the trophic structure of the ecosystem if they are extinct (for example, mammoths, Mammuthus spp., aurochs, Bos taurus primigenius). In addition, populations/communities of native herbivores/predators may not be able to survive or be acceptable to the public in small scale rewilding projects close to areas of high human density or agricultural land. Therefore, the restoration of natural trophic complexity and disturbance regimes within rewilding projects requires careful consideration if the broader conservation needs of society are to be met. Here we highlight the importance of herbivory as a key factor in rewilding. We argue that the use of the suite of livestock species, and in particular traditional breeds, offers the opportunity, under both land sharing/sparing strategies, to reinstate a more "natural" form of herbivory but still retain the option for management interventions (Rewilding Lite). It will even be possible to gain economic returns (ecotourism, sale of livestock products) from these systems, which will make them more acceptable to state and private landowners. We develop our case based on the advantages of using landraces versus de-domestication strategies, and on the implementation of eco-shepherding herbivory as a restoration tool in fine mosaics of agriculture/natural patches. If this approach is adopted, then larger areas can be given over to conservation, because of the potential broader benefits to society from these spaces and the engagement of farmers in practices that are closer to their traditions.
\end{abstract}

Keywords: rewilding; livestock; traditional breeds; ecosystem services; conservation; eco-shepherding

\section{Introduction}

The idea of wilderness has either drawn or repelled humans for millennia. Recall Jesus's journey into the wilderness, a place of angels and devils "At once the Spirit brought him into the desert, where he was tempted by Satan for 40 days. He was there with the wild animals, and the angels took care of him" (Mark 1: 12-13). Whilst human development has spurned the wilderness, seeing it as a place of fear and loathing, Muir and Leopold brought back the idea of wilderness as untrammeled by humans, places of solitude and reflection [1,2]. More recently, there has been a movement, often associated with conservation and ecology, rooted on Soulé and Noss's ideas of rewilding [3], to bring back the wilderness or wild places $[4,5]$. These parts of the landscape are seen as places 
where nature takes its course, on which humans tread lightly and rest a while but do not stay. Rewilding ("large-scale biological and ecological restoration, emphasising recovery of native species ... in natural patterns of abundance, to regain functional and resilient ecosystems" [6,7]) is becoming an umbrella term for a range of human actions to bring back the wild, a religion almost. However, there are differences of opinion about what "proper" rewilding is. As a generalization, the North American approach is more purist than is found in Europe; the latter includes human activity, particularly traditional land uses associated with agriculture (although note that Leopold was not averse to humans' "wise use" of natural resources [2]) [8]. Ultimately though, "A wilderness is an area governed by natural processes... without intrusive or extractive human activity" [9]. Here, we consider two broad types of rewilding: (1) "Rewilding Max"-the rewilding with minimal intervention, covering large areas, with largely intact assemblages of species (i.e., biodiversity) (where intactness is rarely related to a specific historic baseline), and (2) "Rewilding Lite" [10]) -in which carefully chosen interventions are employed to achieve as many of the ecological benefits of rewilding, and with some human economic benefits (for example, sale of animal products, employment) to maximise the area over which ecological benefits (conservation of biodiversity) are achieved (Figure 1).

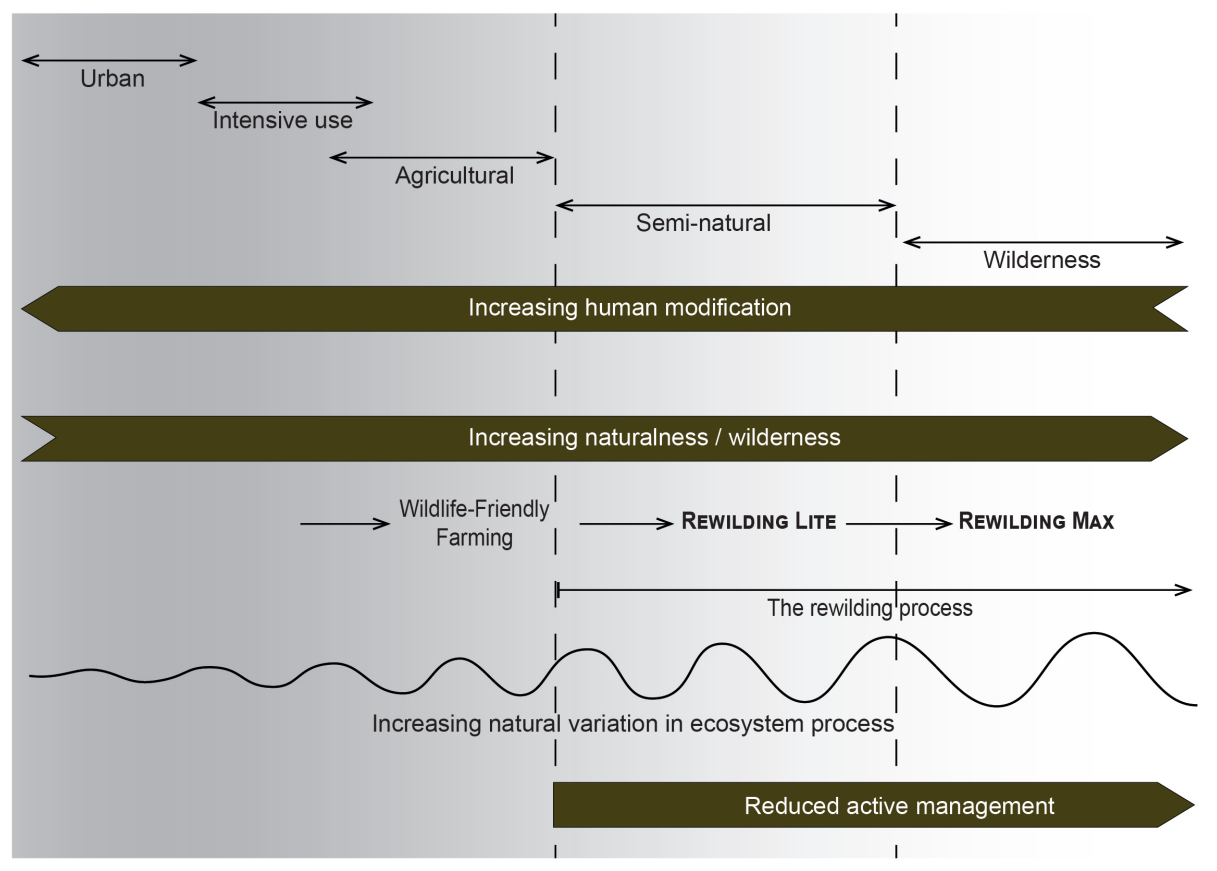

Figure 1. The Wilderness Continuum (sensu [11]) including rewilding. Rewilding is the transitional process from active management to minimal intervention (adapted from [10,11]). On this continuum, Rewilding Lite precedes Rewilding Max, and "wildlife-friendly farming" (sensu [12]) with domestic grazers that are subject to higher levels of husbandry, precede Rewilding Lite. As the conditions become wilder, ecosystems are allowed to operate within a broader range of natural variation (sensu [13]).

Advocates of each type of rewilding are often critical of the other. To characterise, the Rewilding Maxers sometimes consider Rewilding Lite as not legitimate rewilding with too much human influence, and too much compromise to human interests. Meanwhile, Rewilding Liters sometimes consider Rewilding Max as unrealistic, advocating approaches that are unlikely to be achievable without some human intervention, and exclusive of human interests and, therefore, unlikely to achieve public acceptance. Both though are interested in restoring biodiversity - variety of life and its processes at the levels of genetic, population/species, community/ecosystem, and landscape [14], and "self-willed" ecological function. Our view is that the two do not need to be mutually exclusive but sit on a continuum (sensu [10]; Figure 1), and in fact can be mutually reinforcing. This is 
because they are potentially applicable to different parts of the landscape-that is, one is not at the expense of the other. Rewilding Max does not allow for production offtake (but does support ventures such as ecotourism) — which means that many, currently productive pastoral landscapes would be out of scope for rewilding. Rewilding Lite does allow for some productive offtake, and, therefore, could be an alternative form of land management for agricultural land-a much larger area of the earth's surface.

This is where the landscape ecology of rewilding needs to be considered. Wild ecosystems are best embedded in a surrounding matrix that is as similar as possible. Recognizing this, Noss and Harris [13] proposed the creation of a network, of "multiple-use modules" (MUMs), in which protected areas are surrounded by integrated land uses that are complementary to the former. A similar approach was proposed by Harris [15] for forest management. If we adapt these concepts to rewilding, we imagine that Rewilding Max "cores" could be embedded within landscapes of Rewilding Lite (sensu [10]; Figure 2). It is likely that there will always be proportionally less area of Rewilding Max than Rewilding Lite, but together the total area managed to rewilding principles would be far larger than if only one approach were pursued. Critical are the spatial and temporal interactions between the two-Rewilding Max "cores" would build up "ecological memory" (sensu [16] that is, provide founder propagules that "seed" the surrounding Rewilding Lite landscapes through time as embodied in the concept of "Landscape Fluidity" [17]). In this paper, we argue that Rewilding Max and Rewilding Lite are complementary (Figure 2). We focus on how the use of traditional breeds of domestic animals could play an integral part in the adoption of Rewilding Lite, and is a more effective means of delivering desired rewilding outcomes that can also support areas of Rewilding Max.

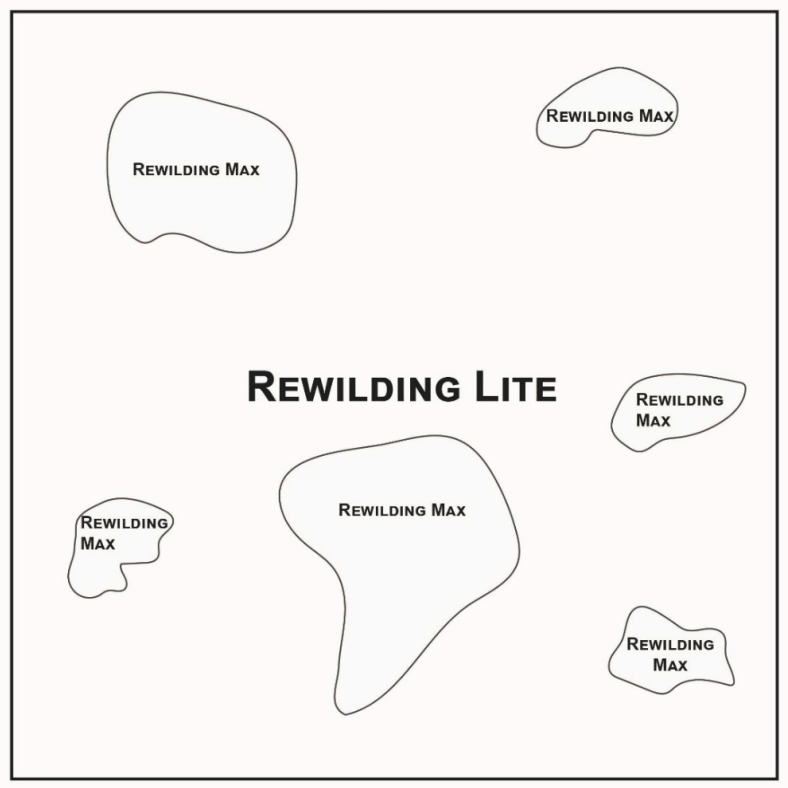

Figure 2. The potential landscape-scale complementarity of Rewilding Max and Rewilding Lite. Rewilding Max "cores" could be embedded in a Rewilding Lite matrix. Hypothetically, the juxtaposition of both "similar" land use types could increase the amount of "effective" habitat for many species that might not otherwise be viable in the landscape, for example, those with larger home ranges than Rewilding Max areas, or requiring specific old-growth features. Rewilding Max cores also provides "ecological memory" in the landscape sensu [16], that is, provide founders propagules that "seed" the surrounding Rewilding Lite landscapes through time as embodied in the concept of "Landscape Fluidity" ([17]). At the same time, Rewilding Lite areas provide a larger area for species that might otherwise be confined (and not viable) in Rewilding Max cores. 


\section{Key Characteristics of Rewilded Ecosystems}

Landscapes managed under rewilding principles would operate within a broader range of natural variation than traditional natural resource management (sensu [13], Figure 1). There are three key ecological components of rewilded ecosystems, that is, (i) stochastic disturbance (the natural frequency and size of events such as herbivory, fire, predation); (ii) dispersal (an organism's ability to move across a landscape); and (iii) trophic complexity (a natural food web allowing, for example, detritivory, herbivory and predation) [18]. Restoration of these natural features of ecosystems requires re-instigation of the drivers of these ecological processes, through healthy soils, and native plant and animal communities, including herbivores and predators (so called "trophic rewilding") [19]. Soulé and Noss's [3] original work envisaged predators playing roles in systems that were essentially driven from the top down; however, herbivory is also a key process that shapes, and has shaped, a range of ecosystem attributes from nutrient cycling through to competitive interactions between plants [20]. Rewilding in this sense is, therefore, a reengagement of ecological processes throughout the ecosystem; it is very much an ecosystemand ecology-centric view of rewilding. The tussle between "top-down" (i.e., predation) and "bottom-up" (that is, growth of vegetation and consumption by herbivores) processes is central to the future feasibility of all types of rewilding. Too much of either, for too long, is likely to drive ecosystem state changes that may be undesirable. The case of population overshoot of "rewilded" herbivores at Oostvaardersplassen (OVP) in the Netherlands is a prime example of an ecosystem where herbivores, without top-down pressure overgrazed and then starved [21,22]. The main challenge for an appropriate re-instigation of the drivers of stochastic disturbance, dispersal, and trophic complexity in rewilded ecosystems is finding out which of these specific drivers, and their intensity, are needed for a particular ecosystem to be effectively rewilded. Without a proper knowledge of these drivers, it will be impossible to make a transition from conceptual to applied effective rewilding initiatives.

How then do we achieve the best for rewilding, unguided, self-organising ecosystems, but avoid undesirable state changes? Where predation by natural predators is absent, OVP demonstrates that it is likely that we will have no choice but to intervene, and to mimic such predation through off-take of herbivores, in all but the largest and most remote settings [22]. This is fundamental to Rewilding Lite- because this means it should be possible to harvest (including through culling or management hunting of "game" animals) and sell meat derived from such management, which provides an economic basis for landowners to convert to rewilding [22]. Central to such an approach would be domestic herbivores that can handle lower levels of husbandry and have meat that has economic value. We contend that locally adapted traditional breeds of livestock are, by definition, ideal for this role, and may be better adapted and provide more valuable products than "de-domesticated" breeds (see below).

\section{Herbivory Is a Key Part of Rewilded Systems}

Herbivory, a key driver of bottom-up processes, is complex with diverse impacts upon the ecosystem in which the community of herbivores exists (Figure 3) [20]. The individual decisions by animal foragers, at small scales, determine the individual plants and the parts of plants that are selected [23]. These decisions are scaled up through the amount of vegetation an individual consumes, how the individual relates to the landscape, and its social context across the day, the week, month, and year [24,25]. The density of herbivores of a species, and the assemblage of herbivores in an ecosystem all determine the distribution and extent of herbivory, and have indirect effects on ecosystems through trampling, rolling, digging, defecation and urination (Figure 3). Large mammalian herbivores are, therefore, essential in any rewilding project or system, and there are good reasons to use our knowledge of herbivore/ecosystem interactions to support the outcomes envisaged in rewilding. 


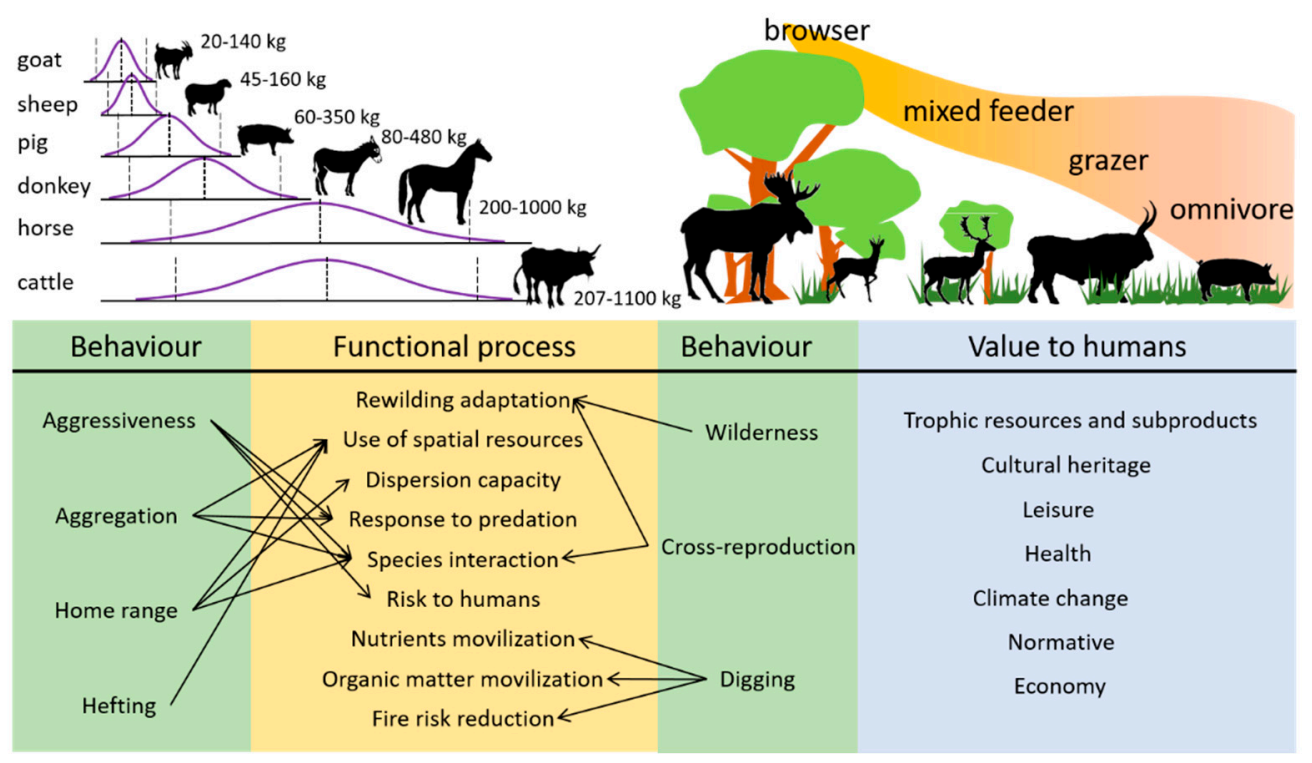

Figure 3. What species/breeds of landraces can be incorporated into Rewilding Lite? We propose classifying species and breeds of domestic livestock within a multidimensional space attending to (i) their potential functional role (as a function of their body size, feeding style and behaviour) and (ii) the benefits for humans. Their position in the multidimensional space will suggest what landraces are appropriate for a specific functional role in a particular environment.

Firstly though, a key consideration in the case for Rewilding Lite, and the use of domestic breeds, is that the growth in the concept and application of rewilding is occurring in a context of increasing stress on ecosystems, with the human population of the globe currently at around 7.5 billion, and likely to reach 9 to 11 billion in the next 30 years [26]. Most of this growth in human population will happen in the developing world. This population is also getting richer [27], leading to changing dietary habits, as people shift from a predominately grain-based diet to one that includes more meat, initially poultry but then pigs, and red meat from goats, sheep and cattle [28,29]. To meet this demand, the projection of land area under permanent pasture in lower- and middle-income countries (particularly in South America and sub-Saharan Africa) for the period 2010-2030 is that it will expand by $\sim 320$ Mha [30]. This will involve an increase in livestock numbers of between $40 \%$ and $50 \%$ for water buffalo, Bubalus bubalis, and cattle, Bos taurus, and 30\% to $45 \%$ for sheep, Ovis aries, and goats, Capra hircus [31]. This additional grazing pressure is likely to increase the stress on rangeland ecosystems used for extensive livestock grazing. This means that putative Rewilding Max core areas of the future will rarely be able to effectively operate within the context of what is happening in the surrounding matrix within which they are embedded. It is worth noting that, as compared to livestock (including pets) that make up $66 \%$ of the total biomass of land mammals today, wildlife including large herbivores make up less than 3\% (and humans the remaining 31\%) [32]. This means that large areas (over $25 \%$ of the Earth's dry surface) has been under agricultural production; much of this is extensive livestock grazing. This has profound effects on the way in which vegetation communities are being, and have been shaped, by large mammalian herbivores, primarily livestock. In many cases rewilding, as often conceptualized, will constitute the abandonment of this agricultural land [33]. Theoretically this could form part of the "land sparing" component of biodiversity conservation [34], where agricultural land is managed intensively to achieve a high yield from relatively small area of the landscape, allowing conversion of remaining areas for conservation [12,34]. Is such managed abandonment, perhaps using Rewilding Max, feasible? Can such a binary approach to whole landscapes achieve biodiversity goals? Will such approaches have the requisite social license?

The proposed alternative to land sparing is "wildlife friendly farming", which is where agriculture and biodiversity are integrated across the whole landscape, but agricultural yields are lower per unit area than under land sparing [12]. Rewilding Lite is a step further 
on the wildness continuum and sits between wildlife-friendly farming and Rewilding Max (Figure 1). The key distinguishing feature is that wildlife-friendly farming (and similar concepts such as High Nature Value farming and conservation grazing) is still focused on production (albeit with biodiversity benefits), whereas Rewilding Lite focusses on delivering wildness, with a co-benefit of meat products (from domestic livestock and game) that can be sold to support the management approach, and mimic top-down (that is, predation) processes [35]. Further, in the former, domestic livestock are still husbanded whereas with Rewilding Lite, husbandry is minimal, and animals are "self-willed", that is, free mate choice, able to form "natural" social structures, and determine their own spatial movements [22]. We contend that Rewilding Lite could be an alternative to more interventionist wildlife-friendly farming (Figure 1).

This concept is highly contentious because domestic livestock have an ambiguous position in conservation and rewilding. Some question their use as a legitimate component of rewilding because livestock are considered as historically part of the "taming" of the wild, that is, that they detract from "wildness". This is particularly the case in Rewilding Max where human activities are separated from natural processes [36]. Others see them as important "tools" to deliver conservation outcomes (for example, [37]). As we outlined above, it is impossible to rewild without restoring herbivory at scale, and domestic livestock are very well adapted to do this. The key question should not be about whether the animal species is wild or domestic, but rather which is most effective to restore the functional ecological processes that we want.

In many areas the wild species that used to graze and browse the landscape are long extinct [38-40]; even when places have been put aside for wildlife, populations of wild native species take a long time to respond, by which time ecosystems may have been tipped into a new, degraded stable state, for example, dominated by fire, shrubs, or weeds [41]. "Herbivory" can be achieved through other means, most of which, for example, controlled burning or slashing, are labour intensive, have limited selectivity at the scale effected by herbivory, and are impractical to apply over large areas. An alternative is for land managers to take a more flexible, deliberative approach to intervening in rewilding projects, and take a second look at traditional domestic breeds to provide the herbivory service in rewilding landscapes (Figure 3). This may only be in the early phase of the project, but it could also need to be continued for many years if wild species are no longer extant or the existing ones are on low numbers.

\section{Key Herbivores Are Extinct or Only Occur in Domesticated Form}

There are, of course, alternatives to the use of domestic livestock in rewilding projects, and we will cover two here (and one in the next section). Firstly, de-extinction, or bringing back species that have become extinct [42]. This has been a pipe dream for many years, with discussions waxing and waning about bringing back, for example, mammoths (Mammuthus spp.) using ancient DNA [43]. To date, the DNA, even from mammoths preserved in permafrost, is not of sufficient quality to use in fertility programmes involving a close relative of the mammoth, that is, the Asian elephant (Elephas maximus). Interestingly, CRISPR-cas9 technology may offer a more cost-effective method of de-extinction using genetic material from close relatives, but that has yet to be tried [44]. Also, de-extinction is not feasible, at least in the foreseeable future for most of the large herbivore species that roamed in Europe, North America, or Australia, as these are now extinct. People are also reluctant to accept long extinct species, viewing them as "alien"; the more ancient the species the more reluctant people are to accept it [19].

Secondly, using extant non-native wild species-Africa retains a relatively intact array of wild species of herbivore that occupy a suite of niches including browsers and grazers of various sizes and digestive systems [45]. A great deal is known about their behavior and ecology in their native ecosystems and specific herbivory requirements can be fulfilled by these species in areas where the native herbivores have been extirpated [46,47]. For example, the hippopotamus (Hippopotamus amphibius) could act as the functional equivalent of the 
extinct semiaquatic notoungulate (Trigonodops lopesi) in South America [48]. Therefore, functional equivalents of extinct species could be released into rewilding areas to perform the role of those lost herbivores [49]. A significant risk with this approach is that the non-native species become invasive and spreading out of the areas of rewilding [50], in themselves causing problems for adjacent land use interests, including conservation. Humans do not have an enviable track record of moving species from their native habitat to new areas-think the cane toad (Rhinella marina) in Australia [51], and goats on many tropical islands [52].

\section{De-Domestication through Selective Breeding to Re-Create "Wild" Herbivores Has Been Proposed as Solution}

Finally, there is the potential to bring back extinct species by "back breeding" domestic species to their progenitors [53]. Much has been made of the Heck cattle, Bos taurus, which were bred to phenotypically resemble the extinct aurochs, Bos primigenius, that roamed Europe until 400 years ago [54], and are depicted in the Neolithic cave paintings in Southern Europe [54]. Heck cattle are the poster child of "de-extinction", however, despite their superficial similarity to the auroch they have issues with respect to management (for example, Oostvaardersplassen see below) [21,22]. Here the attempt to create an unmanaged wild population of Heck cattle, in a reclaimed polder in the Netherlands, ended unsuccessfully, and with considerable loss of public support, when the animals started dying in large numbers over winter because of starvation [21]. More recently, a more evidence-based program has been undertaken to develop an auroch equivalent $[55,56]$. While this is an important project, our question is whether de-domesticated breeds are needed to achieve the desired ecological outcome? This is something that needs to be tested by comparison of the performance of traditional breeds and de-domesticated animals in the wild.

\section{It Is Not Clear That Selectively Bred de-Domesticates Would Be More "Fit" Than Landraces or Be Any Closer in Ecological Impact to the Wild Originals}

The reality is that the reinstatement of the full range of herbivory in many systems is unlikely to be from species that inhabited the region in the past [47]. Even where the rewilding objective is to reinstate the process of trophic complexity using wild herbivores, the reality is that this will take time and is not without significant obstacles [57]. A pragmatic alternative is the use of species of domestic livestock such as sheep, cattle, and goats and even horses, camels, and pigs ([22]; Figure 3).

In the circumstance of rewilding, the approach would be to minimize the management interventions necessary whilst attempting to achieve "natural" herbivory patterns in intensity and distribution. Even defining what is "natural" for a specific place to be rewilded is difficult. Therefore, managers tend to use a proxy of reintroduction of "natural" herbivores. In these cases, particularly where a suite of herbivores is likely to be necessary, the range of livestock species, and the traditional breeds within those species, are likely to offer a broad enough range to achieve this (Figure 3) [58]. There is a generality in what livestock species offer by way of diet and habitat use, for example, goats tend to browse whereas cattle are less selective grazers than are sheep [59]. Maybe not obviously, but there are livestock options other than cattle, sheep and goats that could serve specific purposes, although their adaptations to the environment needs to be assessed (for example, llamas, Llama glama, can survive in harsh European conditions [60,61]).

Due to their importance for food production and draught, much is known about these animals from agricultural science, including physiology, behavior, genetics, and husbandry (for example, over 6500 papers published in 2020 alone (data from Scopus)). The diets and habitat use of livestock on extensive systems is also relatively well understood, as compared to wild species of herbivores (for example, reviews in 2020 [62,63]). Livestock species come from a range of different progenitors and so have a diversity of feeding styles, habitat use and impacts on the ecosystems they inhabit (Figure 3) [58]. As such they can play a range of specific roles in restoring herbivory to rewilding systems [22]. A 
behavioural trait of livestock species that has not been studied is how these species would respond to predators in rewilding. For example, it seems unlikely that a population of sheep survives continuous attacks of a pack of wolves; even goats might have problems to survive, unless the habitat provides them with escape terrain, such as a craggie landscape. On the other hand, larger and aggressive herbivores (horses, donkeys, and cattle) might have a better chance of survival when they live in sympatry with large carnivores.

In the 1980s there was a recognition of the role that domestic livestock could play in conservation [64], with initial specific application in the likes of wetland management for birds in Southern France [37]. Indeed, some innovative conservation organisations and initiatives are using domestic animals in their management toolbox (for example, [65]; and examples in [8]). For example, the Royal Society for the Protection of Birds own several flocks of sheep and herds of cattle that graze to create specific habitats for birds. Further, they employ a farmer to husband their livestock (https:/ / ww2.rspb.org.uk/Images / Farming_at_Haweswater-an_economic_report_2013-2016_tcm9-451498.pdf; accessed on 15 March 2021). Rewilding Lite takes conservation a step further towards wildness. However, we should not "set and step away" in these systems as there is still much to learn about which species/breeds of large herbivores (single or multiple species) are required to create self-sustainable levels of biodiversity in specific ecosystems.

\section{Do Traditional Domestic Landraces Offer Opportunity to Deliver Rewilding and Provide Links to Farmers That Could Expand the Area That Is Managed More Wildly or More Effectively?}

Whilst the context of use of domestic livestock is often very specific within conservation settings, the expectation that rewilding and rewilded landscapes are relatively hands-off, from a human management perspective, means that further thought is needed in its application in these circumstances. It will be essential to avoid the "Oostvaardersplassen Scenario" where the growth of herbivore populations outstrips bottom-up resources, leading to mass die offs and related ecosystem impacts. Managers in the Rewilding Lite context would be best to mimic the top-down effects of natural predators. This will mean selectively culling specific demographics (young and aged, poor health) of the herbivore population [66] to mimic natural predation because this will affect (1) herbivory impacts through herbivore density; (2) the spatial and temporal impacts of herbivory through landscapes of fear (as per Yellowstone National Park); and (3) the adaptation of wild-living landrace populations that are adapted to predation [67].

The minimal intervention required in rewilding projects means that many modern breeds of livestock would not be appropriate because of welfare issues and the lack of self-reliance of these breeds [53]. However, traditional breeds (landraces) can be more hardy than more modern breeds whereby they can survive with little if any management intervention (in effect domestication creates an increased reliance of human input to livestock for them to survive, grow and reproduce) [68]. Traditional breeds could be left to their own devices in the main, with some breeds (for example, Chillingham cattle [69]) having social structures which are close to those one would expect from their wild progenitors, that is, sexual segregation, herd holding and annual ranging patterns. However, in the rewilding context, expecting natural selection to remove domesticated traits, is by no means a foregone conclusion (see below and [70]). More research is required to gain a deeper understanding of the specificities of traditional breeds, including their impacts on ecosystems (e.g., [71]), and their health and welfare requirements in rewilding contexts. There are several instances where the traditional breeds are already playing a part in conservation: for example, on the Isle of Rhum in the Inner Hebrides of Scotland, Highland cattle free-range, maintaining vegetation diversity through removing rank dominant grasses [72]. Also, in the Camargue traditional breeds of horses and cattle maintain herbivory to enhance the structure of wetland communities for birds [64].

One of the key issues of controversy here is the use of de-domesticated animals (for example, Heck cattle and konik horses, Equus caballus) to create the impression of a wild landscape, as compared to the use of landrace traditional breeds. There are, of course, 
philosophical reasons for using the former but there are potential ethical and animal welfare reasons that come into play. As seen in OVP, the de-domesticated breeds may not be able to survive the rigors of natural variation in resource availability, and the public do not necessarily see the deaths of these de-domesticated animals as acceptable [21,53]. Also, there is no clear evidence that de-domesticated breeds, despite having the outward appearance of, for example, aurochs and tarpans, have the same ecology as the extinct species and, therefore, the same impact on ecological processes. Traditional breeds of livestock are, by their nature, adapted to the local circumstances of the rewilding project and are, therefore, more likely to be suited to reduced human inputs and the beneficial impacts on local ecosystems. Whilst there is some research that can be used to inform the decisions being made in rewilding projects (for example, [68-70,72]), this can only be fully understood through real-world experimental trials.

Whilst husbandry practices would have to be light to meet the rewilding philosophy, the OVP scenario shows us that livestock do have to be monitored and that interventions needs to be put in place if the circumstances deem it necessary. One of the key questions for Rewilding Lite is: how much monitoring is enough to be able to intervene when necessary? To some extent this could occur as part of the process of assessing populations for predation-mimicking harvest and framing the management of rewilding projects within a broader rewilding experiment [73]. Furthermore, by instituting a culling regime from the outset of a project, it would also likely mitigate large scale welfare issues, thereby reducing the amount of herd monitoring. It is unlikely that regular veterinary interventions would fit with Rewilding Lite agenda, but there are regulatory requirements in many countries for livestock assessment and tagging [69]. These would likely have to be curtailed in the rewilding projects, but this requires constructive conversations between project managers and policy makers and implementers.

One word of caution, questions still exist about the extent to which the process of domestication has removed natural traits from livestock breeds [74]. For example, the Camargue horses have had relatively little husbandry over many generations, however, they appear to show traits (for example, higher reproductive output and earlier senescence) different from those expected of wild progenitors [70]. Clearly, more research is required but that does not mean managers forego the opportunity of using traditional breeds. Instead, an adaptive management/experimental approach should be used in these types of project, whereby a "model" of the system is developed, clear plans and objectives are put in place, interventions applied, the systems (animals/ecosystem) are monitored, and if any untoward consequences/impacts become apparent, then action can be taken to resolve these (Figure 4).

Except in very rare circumstances, rewilded landscapes will not sit in isolation, but will rather exist within a matrix of land uses (Figure 2), often agriculture or forestry based. The fear of the unknown, for example, predation of livestock by large predators, the potential spread of disease from progenitor species of livestock, could alienate local stakeholders. This means that external stakeholders need to be brought into the fold in support of the rewilding projects. In Europe, many rewilding projects are seen as being driven from outside, or by outsiders to, rural communities (for example, 4,8,35). Bringing traditional breeds of livestock into rewilding projects may reduce the anxiety of neighbours, many of whom are likely already to have experience managing these breeds. Their experience could be sought by rewilding managers as a further means of engagement. So instead of rewilding appearing to be driven by the urban majority, rural communities can become involved in shaping future landscapes, hailing a new era for ruralism. 


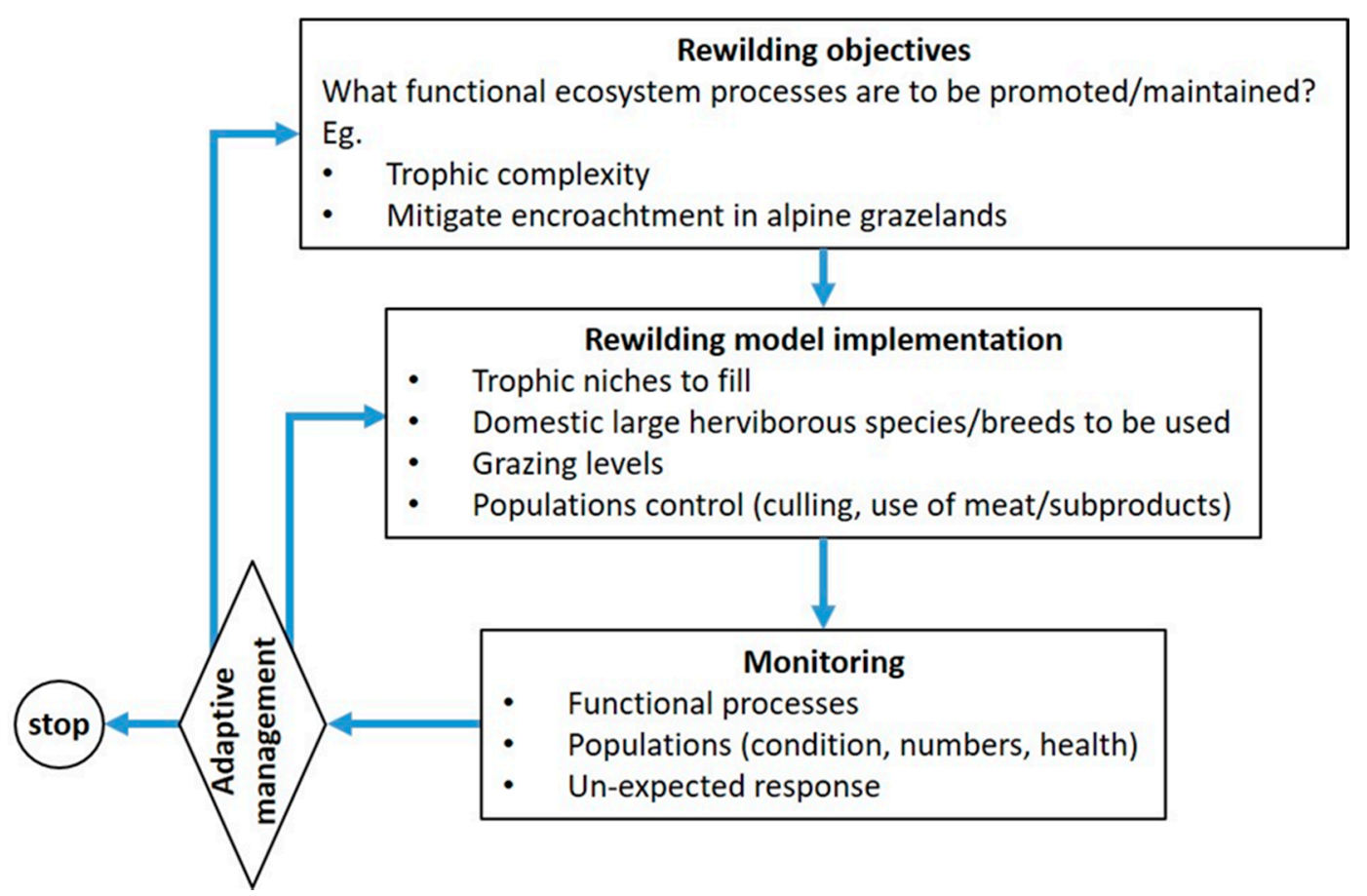

Figure 4. Adaptive management of functional rewilding programmes. Decision-making enables meeting programme objectives and accruing valuable information through output monitoring to improve future management based on a continuous learning process. The challenge lies in minimising learning process time to achieve objectives.

The implementation of rewilding initiatives, using domestic landraces, is a novel concept, and, therefore, requires evidence from "field trials" to demonstrate its functionality in conservation programs. However, monitoring these trials is likely to take years, which would delay the implementation of rewilding with landraces at large scale; postponing the potential ecological and societal benefits for ecosystems and the rural areas communities. Soule [75] pointed out the relevance of pragmatism in conservation biology; for him doing nothing or waiting for a deep knowledge of the ecosystem response to a specific conservation actions, was not an option. Similarly, we advocate for a pragmatic and bold approach to large scale rewilding initiatives, based on the best science and expertise knowledge available to date. This will ensure that we do not continue the deterioration of the landscapes, and do allow local communities, engaged in the rewilding initiatives, to take advantage of its benefits.

8. Use of Traditional Domestic Landraces across the Entire Rewilding and Agricultural Matrix: Eco-Shepherding to Bring Trophic Complexity into Landscapes Dominated by Agricultural Systems

Wild herbivores, that exist in a fine mosaic of agriculture/natural land patches are likely to generate conflicts because of impacts on agricultural interests. In Europe, $46 \%$ of the land cover corresponds to agricultural land and human infrastructure, and $49 \%$ is forest or semi-natural areas [76]. There are few large areas of natural habitats where the implementation of rewilding programmes, using large herbivores, will not risk conflict with farming interests. Among the few large natural areas where rewilding might be societally accepted in Europe are mountain ranges and natural and semi-natural forest and scrubland; a good example of the latter is Scandinavian prime and forestry woodland, though even these are not completely conflict-free [77].

A different approach to rewilding is needed to regulate ecosystem processes and introduce trophic complexity in areas where rural abandonment has led to very low human densities, but where the agricultural component of the landscape matrix dominates, as is the predominant situation in southern Europe. A good example is the north plateau 
of Spain, an area of 50,000 $\mathrm{km}^{2}$ dominated by cereal crops interspersed with patches of forest, riparian vegetation and other linear landscape features, and with ample areas where human densities average below 2.5 people $/ \mathrm{km}^{2}$ (www.ine.es; accessed on 15 March 2021). This contrasts with southern Scandinavia, where the natural component of the landscape matrix is considerable and crop damage by wild large herbivores is offset by the hunting profit that these species bring into the rural communities [78]. We propose that in places where the agricultural component of the landscape matrix is predominant, and the agricultural/natural mosaic is complex, traditional shepherding can be encouraged as a rewilding tool. The type of shepherding proposed is that in which the shepherd moves with the herd and makes decisions on where, when and for how long the herd grazes, as is common in the Alps [79]. This has a long tradition in Spain where it was the basis of one of the most important guilds in Europe during the Middle Age, the Livestock Mesta Council ("Honrado Concejo de la Mesta") founded by Alfonso X of Castile in 1273; thousands of kilometres of protected transhumance routes have survived until now [80]. This "eco-shepherding" differs from hefting flock management, in which livestock learn to stay within a limited unfenced area through mother-offspring cultural transmission across generations, requiring the limited presence of the shepherd. The eco-shepherding proposed not only reduces crop damage, but also minimises excessive grazing of ecologically sensitive, restores historically overgrazed areas, and reduces the risk of wolf, Canis lupus, attacks. Shepherds should be provided with an agreed protocol of biodiversity-friendly grazing, but also with new legislation and market frameworks (tax reductions or certifying low carbon trading products) that support profitable livestock farming. These protocols could be incorporated into the teaching programmes of the shepherd schools that have flourished across Europe in recent years.

Although there is no room here for developing biodiversity-friendly shepherding protocols, some overarching guidelines are provided here. Mixed livestock eco-flocks should be encouraged to bring trophic complexity to the system. In the past mixed flocks of sheep and goats were very common in southern Europe, however, they have become a rarity nowadays. Multi-species flocks, formed by species/breeds of very different body size and feeding and digestive strategies (Figure 3) [81], could be trialled to assess the logistic problems of their shepherding, and the compatibility of behavioural patterns between species/breeds [82,83]. In this eco-shepherding approach, initiatives of producing locally sourced dairy products of mixed species milk could be promoted, together with informing the consumer about the benefits to the environment of these products. In the Mediterranean, traditional shepherding using donkeys, Equus asinus, as draught animals was common in the past, however, this is a rare practice in current times. However, the few shepherds who still use donkeys sing their praises, because of the donkeys' low maintenance, hardiness, the possibility of carrying food, drinks, clothes, newborn lambs, transport in case of accident, and for their company (Pérez-Barbería, personal observation). The effects of grazing by horses and their relatives on vegetation are different from those effects produced by ruminant grazing $[84,85]$, independent of differences due to body size between species [86]. Encouraging the use of donkeys in eco-shepherding could have benefits, other than draught, as this would add to trophic complexity and helping to maintain donkey populations in European countries. Promoting traditional shepherding in these complex agriculture/natural mosaics also provides a tool for the sustainability of corridors to increase connectivity [87], and to reduce the accumulation of vegetation biomass and the resulting risk of wildfires [88].

\section{Further Development/Consideration, e.g., Policy and Regulations, Research on Differing Ecosystem Effects}

There is significant, and growing, interest amongst scientists and advocacy groups in rewilding large parts of our landscapes. Indeed, policy makers and regulators appear to be open to the notion of continuing subsidy payments for livestock being used in contexts where there is clear public benefit for the ecosystem services they provide. In the UK and the European Union agri-environment schemes could allow domestic livestock, particularly 
traditional breeds, to be supported within rewilding projects [89]. There are also economic rationales for landowners to implement rewilding on their land through livestock products being sold in increasingly discerning markets [22]. There is obviously a need to ensure that the public provides the social license for rewilding to operate. The involvement of human interventions, no matter how "lite" (for example, traditional breeds and culling wildlife), will require further study.

The growth of rewilding projects in Europe is very heartening [8], as is the use of traditional breeds within these projects [22]. There are, however, greater opportunities than are currently being taken to use livestock to instigate diverse herbivory profiles across large swathes of land. This will require a change in mindset of managers, conservationists, policy makers and regulators, allowing the vast toolbox of traditional breeds (for example, there are over 1000 recognised breeds of cattle) to be used to reinstate ecological levels and types to implement herbivory that mimics natural impacts on ecosystems to achieve rewilding outcomes. This would align with the agricultural biodiversity initiatives in the Convention of Biological Diversity (https://www.cbd.int/agro/about.shtml; accessed on 15 March 2021). However, the relative ecological performance of de-domesticated versus traditional landraces in delivering desired rewilding outcomes needs further experimental investigation. Furthermore, the spatial or landscape ecology of the use of Rewilding Lite and Rewilding Max as complementary ways to achieve landscape-scale rewilding (Figure 2) would be a valuable direction for future research.

There is always the option, in the future, for areas managed under Rewilding Lite to progress towards Rewilding Max (Figure 1) —indeed it may be the fastest route to achieving the latter if the former helps develop the landscape structure and function that is hard to achieve in single leap. Sometimes the pure is the enemy of the pragmatic. Instead of a dichotomy of views of the ideal outcome, we need to concentrate on practical approaches to achieving a continuum of landscapes that includes more wildness and that allows nature and humanity to live together, nurturing the common good.

Author Contributions: Conceptualization, I.J.G., F.J.P.-B. and A.D.M.; Writing-original draft preparation, I.J.G.; Writing-review and editing, F.J.P.-B. and A.D.M. All authors have read and agreed to the published version of the manuscript.

Funding: F.J.P.-B. is grateful to programme Beatriz Galindo 2020 (Spanish Plan Estatal de Política Científica y Técnica y de Innovación CNU /692/2019) for financial support.

Institutional Review Board Statement: Not applicable.

Informed Consent Statement: Not applicable.

Acknowledgments: We thank two reviewers for their comments on the manuscript. Their suggestions have helped us clarify several of the points we are making in this review.

Conflicts of Interest: The authors declare no conflict of interest.

\section{References}

1. Muir, J. Our National Parks; Houghton Mifflin: Boston, MA, USA, 1901; ISBN 978-1423650393.

2. Leopold, A. Wilderness as a form of land use. J. Land Public Util. Econ. 1925, 1, 398-404. [CrossRef]

3. Soulé, M.E.; Noss, R. Rewilding and biodiversity: Complementary goals for continental conservation. Wild Earth 1998, 8, 19-28.

4. Monbiot, G. Feral: Rewilding the Land, the Sea, and Human Life; University of Chicago Press: Chicago, IL, USA, 2014.

5. Pettorelli, N.; Durant, S.M.; Du Toit, J.T. (Eds.) Rewilding; Cambridge University Press: Cambridge, UK, 2019.

6. Johns, D. History of rewilding: Ideas and practice. In Rewilding; Pettorelli, N., Duran, S.M., Du Toit, J.T., Eds.; Cambridge University Press: Cambridge, UK, 2019; pp. 12-33.

7. Noss, R.F. The Wildlands Project: Land Conservation Strategy. Wild Earth Spec. Issue 1992, 10, e25.

8. $\quad$ Pereira, H.M.; Navarro, L.M. (Eds.) Rewilding European Landscapes; Springer: New York, NY, USA, 2015.

9. Wild Europe Initiative. A Working Definition of European Wilderness and Wild Areas; Wild Europe Initiative: London, UK, 2013.

10. Carver, S. Making real space for nature: A continuum approach to UK conservation. ECOS 2014, 35, 4-14.

11. Lesslie, R.G.; Taylor, S.G. The wilderness continuum concept and its implications for Australian wilderness preservation policy. Biol. Conserv. 1985, 32, 309-333. [CrossRef] 
12. Fischer, J.; Brosi, B.; Daily, G.C.; Ehrlich, P.R.; Goldman, R.; Goldstein, J.; Lindenmayer, D.B.; Manning, A.D.H.; Mooney, A.; Pejchar, L.; et al. Should agricultural policies encourage land sparing or wildlife-friendly farming? Front. Ecol. Environ. 2008, 6, 380-385. [CrossRef]

13. Noss, R.F.; Harris, L.D. Nodes, networks, and MUMs: Preserving diversity at all scales. Environ. Manag. 1986, 10, $299-309$. [CrossRef]

14. Noss, R.F.; Cooperrider, A.Y. Saving Nature's Legacy: Protecting and Restoring Biodiversity; Island Press: Washington, DC, USA, 1994.

15. Harris, L.D. The Fragmented Forest: Island Biogeography Theory and the Preservation of Biotic Diversity; The University of Chicago Press: Chicago, IL, USA, 1984.

16. Bengtsson, J.; Angelstam, P.; Elmqvist, T.; Emanuelsson, U.; Folke, C.; Ihse, M.; Moberg, F.; Nystrom, M. Reserves, resilience and dynamic landscapes. Ambio 2003, 32, 389-396. [CrossRef] [PubMed]

17. Manning, A.D.; Fischer, J.; Felton, A.; Newell, B.; Steffen, W.; Lindenmayer, D.B. Landscape fluidity-a unifying perspective for understanding and adapting to global change. J. Biogeogr. 2009, 36, 193-199. [CrossRef]

18. Perino, A.; Pereira, H.M.; Navarro, L.M.; Fernández, N.; Bullock, J.M.; Ceauşu, S.; Cortés-Avizanda, A.; van Klink, R.; Kuemmerle, T.; Lomba, A.; et al. Rewilding complex ecosystems. Science 2019, 364, eaav5570. [CrossRef]

19. Svenning, J.-C.; Pedersen, P.B.M.; Donlan, C.J.; Ejrnæs, R.; Faurby, S.; Galetti, M.; Hansen, D.M.; Sandel, B.; Sandom, C.J.; Terborgh, J.W.; et al. Science for a wilder Anthropocene: Synthesis and future directions for trophic rewilding research. PNAS 2016, 949113, 898-906. [CrossRef]

20. Gordon, I.J.; Prins, H.H.T. (Eds.) The Ecology of Browsing and Grazing II; Springer: New York, NY, USA, 2019.

21. Theunissen, B. The Oostvaardersplassen fiasco. ISIS 2019, 110, 341-345. [CrossRef]

22. Gordon, I.J.; Manning, A.D.; Navarro, L.M.; Rouet-Leduc, J. Domestic livestock and rewilding: Are they mutually exclusive? Front. Sustain. Food Syst. 2021, 5, 68. [CrossRef]

23. McNaughton, S.J. Grazing lawns-animals in herds, plant form, and coevolution. Am. Nat. 1984, 124, 863-886. [CrossRef]

24. Senft, R.L.; Coughenour, M.B.; Bailey, D.W.; Rittenhouse, L.R.; Sala, O.E.; Swift, D.M. Large herbivore foraging and ecological hierarchies. BioScience 1987, 37, 789-799. [CrossRef]

25. Beguin, J.; Tremblay, J.P.; Thiffault, N.; Pothier, D.; Côté, S.D. Management of forest regeneration in boreal and temperate deer-forest systems: Challenges, guidelines, and research gaps. Ecosphere 2016, 7, e01488. [CrossRef]

26. United Nations. Department of Economic and Social Affairs, Population Division (2019). World Population Prospects 2019: Highlights (ST/ESA/SER.A/423); United Nations General Assembly: New York, NY, USA, 2019.

27. World Bank. 2021 World Bank Data for Low and Middle Income Countries. Available online: https://data.worldbank.org/ income-level/low-and-middle-income (accessed on 10 February 2021).

28. Delgado, C.; Rosegrant, M.; Steinfeld, H.; Ehui, S.; Courbois, C. Livestock to 2020: The Next Food Revolution; International Food Policy Research Institute: Washington, WA, USA, 1999.

29. Alexandratos, N.; Bruinsma, J. World Agriculture Towards 2030/2050: The 2012 Revision. ESA Working Paper No. 12-03; Food and Agriculture Organization: Rome, Italy, 2012.

30. Wirsenius, S.; Azar, C.; Berndes, G. How much land is needed for global food production under scenarios of dietary changes and livestock productivity increases in 2030? Agric. Syst. 2010, 103, 621-638. [CrossRef]

31. Bruinsma, J. (Ed.) World Agriculture: Towards 2015/2030. An. FAO Perspective; Food and Agriculture Organization: Rome, Italy; Earthscan Publications: London, UK, 2003.

32. Bar-On, Y.M.; Phillips, R.; Milo, R. The biomass distribution on Earth. Proc. Natl. Acad. Sci. USA 2018, 115, 6506-6511. [CrossRef] [PubMed]

33. Navarro, L.M.; Pereira, H.M. Rewilding abandoned landscapes in Europe. Ecosystems 2012, 15, 900-912. [CrossRef]

34. Green, R.E.; Cornell, S.J.; Scharlemann, J.P.W.; Balmford, A. Farming and the fate of wild nature. Science 2005, 307, 550-555. [CrossRef] [PubMed]

35. Tree, I. Wilding; Picador: London, UK, 2018.

36. Jørgensen, D. Rethinking rewilding. Geoforum 2015, 65, 482-488. [CrossRef]

37. Gordon, I.J.; Duncan, P.; Grillas, P.; Lecomte, T. Conservation of the biological richness of European wetlands: The role of domestic ungulates. Bull. D'ecol. 1990, 21, 49-60.

38. Martin, P.S. The Discovery of America: The first Americans may have swept the Western Hemisphere and decimated its fauna within 1000 years. Science 1973, 179, 969-974. [CrossRef]

39. Johnson, C.N.; Alroy, J.; Beeton, N.J.; Bird, M.I.; Brook, B.W.; Cooper, A.; Gillespie, R.; Herrando-Pérez, S.; Jacobs, Z.; Miller, G.H.; et al. What caused extinction of the Pleistocene megafauna of Sahul? Proc. R. Soc. B Biol. Sci. 2016, 283, 20152399. [CrossRef] [PubMed]

40. Rowan, J.; Faith, J.T. The paleoecological impact of grazing and browsing: Consequences of the late Quaternary megafaunal extinctions. In The Ecology of Browsing and Grazing II; Gordon, I.J., Prins, H.H.T., Eds.; Springer: New York, NY, USA, 2019; pp. 61-79.

41. van Langevelde, F.; van de Vijver, C.A.; Prins, H.H.; Groen, T.A. Effects of Grazing and Browsing on Tropical Savanna Vegetation. In The Ecology of Browsing and Grazing II; Gordon, I.J., Prins, H.H.T., Eds.; Springer: New York, NY, USA, 2019 ; pp. $237-257$.

42. Shapiro, B. How to Clone a Mammoth: The Science of De-Extinction; Princeton University Press: Princeton, NJ, USA, 2015.

43. Seddon, P.J. De-extinction and barriers to the application of new conservation tools. Recreating Wild De-extinction Technol. Ethics Conserv. Spec. Rep. Hastings Cent. Rep. 2017, 47, S5-S8. [CrossRef] [PubMed] 
44. Kolodziejczyk, B.; Kofler, N.; Araya, M.; Bull, J.; Champer, J.; Liu, C.; Yuthavong, Y. Synthetic Biology: Re-engineering the environment. In Frontiers 2018/19: Emerging Issues of Environmental Concern; UNEP: Nairobi, Kenya, 2019 ; Chapter 1.

45. Lundgren, E.J.; Ramp, D.; Rowan, J.; Middleton, O.; Schowanek, S.D.; Sanisidro, O.; Carroll, S.P.; Davis, M.; Sandom, C.J.; Svenning, J.C.; et al. Introduced herbivores restore Late Pleistocene ecological functions. Proc. Natl. Acad. Sci. USA 2020, 117, 7871-7878. [CrossRef] [PubMed]

46. Kingdon, J. East African Mammals: An Atlas of Evolution in Africa; Academic Press Inc.: London, UK, 1971; Volume I.

47. Donlan, J. Re-wilding north America. Nature 2005, 436, 913-914. [CrossRef]

48. Lundgren, E.J.; Ramp, D.; Ripple, W.J.; Wallach, A.D. Introduced megafauna are rewilding the Anthropocene. Ecography 2018, 41, 857-866. [CrossRef]

49. Bakker, E.S.; Svenning, J.-C. Trophic rewilding: Impact on ecosystems under global change. Philos. Trans. R. Soc. B 2018, 373, 20170432. [CrossRef] [PubMed]

50. Shurin, J.B.; Aranguren-Riaño, N.; Duque Negro, D.; Echeverri Lopez, D.; Jones, N.T.; Laverde, R.O.; Neu, A.; Pedroza Ramos, A. Ecosystem effects of the world's largest invasive animal. Ecology 2020, 101, e02991. [CrossRef]

51. Doody, J.S.; McHenry, C.; Letnic, M.; Everitt, C.; Sawyer, G.; Clulow, S. Forecasting the spatiotemporal pattern of the cane toad invasion into north-western Australia. Wildl. Res. 2019, 45, 718-725. [CrossRef]

52. Schofield, E.K. Effects of introduced plants and animals on island vegetation: Examples from Galápagos Archipelago. Conserv. Biol. 1989, 3, 227-239. [CrossRef]

53. Gamborg, C.; Gremmen, B.; Christiansen, S.B.; Sandøe, P. De-domestication: Ethics at the intersection of landscape restoration and animal welfare. Environ. Values 2010, 1, 57-78. [CrossRef]

54. Heck, H. The breeding-back of the Aurochs. Oryx 1951, 1, 117-122. [CrossRef]

55. Goderie, R.; Lenstra, J.A.; Upadhyay, M.; Crooijmans, R.; Linnartz, L. Aurochs Genetics, a Cornerstone of European Biodiversity. Rewilding Europe. Available online: https://www.rewildingeurope.com/wp-content/uploads/2016/01/Aurochs-genetics_ summary_final.pdf (accessed on 8 January 2021).

56. Rewilding Europe The Aurochs-Europe's Defining Animal. Available online: https://rewildingeurope.com/rewilding-inaction/wildlife-comeback/tauros/ (accessed on 1 April 2020).

57. Prior, J.; Ward, K.J. Rethinking rewilding: A response to Jørgensen. Geoforum 2016, 69, 132-135. [CrossRef]

58. Rook, A.J.; Dumont, B.; Isselstein, J.; Osoro, K.; WallisDeVries, M.F.; Parente, G.; Mills, J. Matching type of livestock to desired biodiversity outcomes in pastures-a review. Biol. Conserv. 2004, 119, 137-150. [CrossRef]

59. Gordon, I.J.; Fraser, M.D. Foraging ecology of fibre producing ruminant species. In Alternative Animals for Fibre Production; Russel, A.J.F., Ed.; EEC Publications: Brussels, Belgium, 1991; pp. 65-78.

60. Fraser, M.D.; Gordon, I.J. The diet of goats, red deer and South American camelids feeding on three contrasting Scottish vegetation communities. J. Appl. Ecol. 1997, 34, 668-686. [CrossRef]

61. Galbraith, H.; Antonini, M.; Gerken, M.; Gutiérrez Garcia, J.P.; Niznikowski, R.; Renieri, C.; Wurzinger, M.; Allain, D. Species, breeds and potential for improvement in animal fibre production in Europe. In Book of Abstracts of the 67th Annual Meeting of the European Association for Animal Production; Wageningen Academic Publishers: Wageningen, The Netherlands, 2016 ; p. 519.

62. Stampa, E.; Schipmann-Schwarze, C.; Hamm, U. Consumer perceptions, preferences, and behavior regarding pasture-raised livestock products: A review. Food Qual. Prefer. 2020, 82, 103872. [CrossRef]

63. Martin, G.; Barth, K.; Benoit, M.; Blanc, M.; Brock, C.; Destruel, M.; Dumont, B.; Hübner, S.; Magne, M.A.; Moerman, M.; et al. Potential of multi-species livestock farming to improve the sustainability of livestock farms: A review. Agric. Syst. 2020, 181, 102821. [CrossRef]

64. Gordon, I.J.; Duncan, P.; Gleize, J.C. Gestion des resource naturelles: Le champ libre aux tropeaux domestiques. Bull. Mens. Off. Natl. Chass. 1989, 136, 25-30.

65. Overend, D.; Lorimer, J. Wild performatives: Experiments in rewilding at the Knepp Wildland Project. GeoHumanities 2018, 4, 527-542. [CrossRef]

66. Ritchie, E.G.; Johnson, C.N. Predator interactions, mesopredator release and biodiversity conservation. Ecol. Lett. 2009, 12, 982-998. [CrossRef]

67. Ripple, W.J.; Beschta, R.L. Wolves and the ecology of fear: Can predation risk structure ecosystems? BioScience 2004, 54, 755-766. [CrossRef]

68. Tolhurst, S.; Oates, M. The Breed. Profiles Handbook; English Nature: Peterborough, UK, 2001.

69. Hall, S.J.; Fletcher, J.; Gidlow, J.; Ingham, B.; Shepherd, A.; Smith, A.; Widdows, A. Management of the Chillingham wild white cattle. Gov. Vet. J. 2005, 15, 4-11.

70. Grange, S.; Duncan, P.; Gaillard, J.M. Poor horse traders: Large mammals trade survival for reproduction during the process of feralization. Proc. R. Soc. B Biol. Sci. 2009, 276, 1911-1919. [CrossRef] [PubMed]

71. Hall, S.J.; Bunce, R.G. The use of cattle Bos taurus for restoring and maintaining holarctic landscapes: Conclusions from a long-term study (1946-2017) in northern England. Ecol. Evol. 2019, 9, 5859-5869. [CrossRef] [PubMed]

72. Gordon, I.J.; Dunbar, R.I.M.; Buckland, D.; Miller, D. Ponies, cattle and goats. In Rhum: The Natural History of an Island; Clutton-Brock, T.H., Ball, M.E., Eds.; Edinburgh University Press: Edinburgh, UK, 1987; pp. 110-125.

73. Jepson, P.A. Rewilding agenda for Europe: Creating a network of experimental reserves. Ecography 2016, 39, 117-124. [CrossRef]

74. Clutton-Brock, J. Domesticated Animals from Early Times; Heinemann/ British Museum (Natural History): London, UK, 1981. 
75. Soulé, M.E.Z. What is Conservation Biology? A new synthetic discipline addresses the dynamics and problems of perturbed species, communities, and ecosystems. BioScience 1985, 35, 727-734. [CrossRef]

76. CORINE Coordination of Information on the Environment; European Environment Agency: Brussels, Belgium, 2018.

77. Jarnemo, A.; Minderman, J.; Bunnefeld, N.; Zidar, J.; Månsson, J. Managing landscapes for multiple objectives: Alternative forage can reduce the conflict between deer and forestry. Ecosphere 2014, 5, art97. [CrossRef]

78. Menichetti, L.; Touzot, L.; Elofsson, K.; Hyvönen, R.; Kätterer, T.; Kjellander, P. Interactions between a population of fallow deer (Dama dama), humans and crops in a managed composite temperate landscape in southern Sweden: Conflict or opportunity? PLoS ONE 2019, 14, e0215594. [CrossRef]

79. Meuret, M.; Provenza, F. The Art E Science of Shepherding: Tapping the Wisdom of French Herders; ACRES USA: Austin, TX, USA, 2014.

80. Mangas Navas, J. Cuadernos de la Trashumancia: Vias Pecuarias, Cuadernos de la Trashumancia; Ministerio de Agricultura: Madrid, Spain; Alimentación y Medio Ambiente: Madrid, Spain, 2012.

81. Pérez-Barbería, F.J.; Elston, D.A.; Gordon, I.J.; Illius, A.W. The evolution of phylogenetic differences in the efficiency of digestion in ruminants. Proc. R. Soc. B-Biol. Sci. 2004, 271, 1081-1090. [CrossRef] [PubMed]

82. Mysterud, A.; Perez-Barberia, F.J.; Gordon, I.J. The effect of season, sex and feeding style on home range area versus body mass scaling in temperate ruminants. Oecologia 2001, 127, 30-39. [CrossRef] [PubMed]

83. Pérez-Barbería, F.J.; Robertson, E.; Soriguer, R.; Aldezabal, A.; Mendizabal, M.; Perez-Fernandez, E. Why do polygynous ungulates segregate in space? Testing the activity-budget hypothesis in Soay sheep. Ecol. Monogr. 2007, 77, 631-647. [CrossRef]

84. Edouard, N.; Fleurance, G.; Martin-Rosset, W.; Duncan, P.; Dulphy, J.P.; Grange, S.; Baumont, R.; Dubroeucq, H.; PérezBarbería, F.J.; Gordon, I.J. Voluntary intake and digestibility in horses: Effect of forage quality with emphasis on individual variability. Animal 2008, 2, 1526-1533. [CrossRef] [PubMed]

85. Sharpe, P. Horse Pasture Management, 1st ed.; Academic Press: London, UK, 2018.

86. Farnsworth, K.D.; Focardi, S.; Beecham, J.A. Grassland-herbivore interactions: How do grazers coexist? Am. Nat. 2002, 159, 24-39. [CrossRef] [PubMed]

87. Manzano, P.; Malo, J.E. Extreme long-distance seed dispersal via sheep. Front. Ecol. Env. 2006, 4, 244-248. [CrossRef]

88. Johnson, C.N.; Prior, L.D.; Archibald, S.; Poulos, H.M.; Barton, A.M.; Williamson, G.J.; Bowman, D.M.J.S. Can trophic rewilding reduce the impact of fire in a more flammable world? Philos. Trans. R. Soc. B-Biol. Sci. 2018, 373, 20170443. [CrossRef]

89. Hall, S.J. Livestock biodiversity as interface between people, landscapes and nature. People Nat. 2019, 1, 284-290. [CrossRef] 